\title{
Dermatitis in humans caused by Ornithonyssus bursa (Berlese 1888) (Mesostigmata: Macronyssidae) and new records from Brazil
}

\author{
Dermatite em humanos causada por Ornithonyssus bursa (Berlese 1888) (Mesostigmata: Macronyssidae) \\ e novos registros para o Brasil
}

\author{
Ricardo Bassini-Silva ${ }^{1}$ (1); Fernando de Castro Jacinavicius ${ }^{1,2}$ (1); Fabio Akashi Hernandes ${ }^{3}$ (1) Ronald Ochoa ${ }^{4}$ (i), \\ Gary R. Bauchan ${ }^{5}\left(\mathbb{0}\right.$, Ashley P. G. Dowling ${ }^{6}$ (D), Darci Moraes Barros-Battesti ${ }^{1,7 *}$ (D)
}

\begin{abstract}
${ }^{1}$ Departamento de Medicina Veterinária Preventiva e Saúde Animal, Faculdade de Medicina Veterinária e Zootecnia da Universidade de São Paulo - FMVZ-USP, São Paulo, SP, Brasil

${ }^{2}$ Laboratório Especial de Coleçóes Zoológicas, Instituto Butantan, São Paulo, SP, Brasil

${ }^{3}$ Departamento de Zoologia, Universidade Estadual Paulista - UNESP, Rio Claro, SP, Brasil

${ }^{4}$ Systematic Entomology Laboratory, United States Department of Agriculture, Agricultural Research Service, Beltsville, MD, USA

${ }^{5}$ Electron \& Confocal Microscopy Unit, United States Department of Agriculture, Agriculture Research Service, Beltsville, MD, USA

${ }^{6}$ Department of Entomology, University of Arkansas, Fayetteville, AR, USA

${ }^{7}$ Departamento de Patologia Veterinária, Faculdade de Ciências Agrárias e Veterinárias, Universidade Estadual Paulista - UNESP, Jaboticabal, SP, Brasil
\end{abstract}

Received October 31, 2018

Accepted December 17, 2018

\begin{abstract}
Ornithonyssus bursa, known as the "tropical fowl mite", is a hematophagous mite of domestic and wild birds, occasionally biting humans. Infestation on humans occurs mainly when the abandoned nests are close to homes, or by manipulation of infested birds by humans. In Brazil, this species occurs in the south and southeast of the country. In the present study we are reporting bites on humans, new localities records, host associations, and molecular information of $O$. bursa.
\end{abstract}

Keywords: "Tropical fowl mite", human parasitism, dermatitis, Brazil.

\section{Resumo}

Ornithonyssus bursa, conhecido como "ácaro tropical de galinha”, é um ácaro hematófago de aves domésticas e silvestres, ocasionalmente picando humanos. A infestação em humanos ocorre principalmente quando os ninhos abandonados de aves estão próximos de casas, ou pela manipulação de humanos de aves infestadas. No Brasil, esta espécie ocorre na região sul e sudeste do país. No presente estudo, estamos relatando picadas em humanos, registros de novas localidades de ocorrência, novo hospedeiro e informaçóes moleculares de O. bursa.

Palavras-chave: "Ácaro tropical de galinha”, parasitismo em humanos, dermatite, Brasil.

\section{Introduction}

The mite Ornithonyssus bursa (Berlese, 1888) (Mesostigmata: Macronyssidae) is known as the "tropical fowl mite", a hematophagous mite, mainly parasitizing wild and domestic birds, but occasionally biting humans (DENMARK \& CROMROY, 2003).

This mite can cause lesions with intense pruritus, even killing the host (COIMBRA et al., 2012; MASCARENHAS et al., 2009).

*Corresponding author: Darci Moraes Barros Battesti. Departamento de Patologia Veterinária, Faculdade de Ciências Agrárias e Veterinárias, Universidade Estadual Paulista - UNESP, Via de Acesso Professor Paulo Donato Castelane, s/n, Vila Industrial, CEP 14884-900, Jaboticabal, SP, Brasil. e-mail: barros.battesti@gmail.com
In addition to the records on domestic birds, this species has been reported in the nests of Agelaius xanthomus (Passeriformes: Icteridae) in Puerto Rico (POST, 1981) and in nests of Myiopsitta monachus (Psittaciformes: Psittacidae) in Argentina (ARAMBURÚ et al., 2002).

In Brazil, there are records of this mite associated with young birds of the species Megascops choliba (Strigiformes: Strigidae), Pitangus sulphuratus (Passeriformes: Tyrannidae) (MASCARENHAS et al., 2009), and Columbina talpacoti (MORAES et al., 2011). A study in the state of São Paulo by Goulart et al. (2011) recorded O. bursa parasitizing Zenaida auriculata (Columbiformes: Columbidae) 
and Silva et al. (2018) recorded this species in the state of Rio Grande do Sul on nests of Vanellus chilensis (Charadriiformes: Charadriidae), Gallinago paraguaiae (Charadriiformes: Scolopacidae), Columbina picui, C. talpacoti, Leptotila verreauxi and Zenaida auriculata (Columbiformes: Columbidae), Anumbius annumbi and Certhiaxis cinnamomeus (Passeriformes: Furnariidae), Progne tapera (Passeriformes: Hirundinidae), Cacicus chrysopterus (Passeriformes: Icteridae), Mimus saturninus (Passeriformes: Mimidae), Zonotrichia capensis (Passeriformes: Passerellidae), Basileuterus culicivorus (Passeriformes: Parulidae), Turdus albicollis and T. leucomelas (Passeriformes: Turdidae), Paroaria coronata and Sicalis flaveola (Passeriformes: Thraupidae), Pitangus sulphuratus and Xolmis irupero (Passeriformes: Tyrannidae) and Nothura maculosa (Tinamiformes: Tinamidae). Besides that, this species is commonly found parasitizing backyarding chickens in Brazil (GUIMARÁES et al., 2001).

Infestation on humans occurs mainly when abandoned nests are close to homes, or by manipulation of infested birds by humans (RIBEIRO \& GIORA, 1994; SEMENAS \& ROCHA, 1998). The parasitism causes itch, temporary lesions and even painful dermatitis (RIBEIRO et al., 1992; DENMARK \& CROMROY, 2003).

The first report of human dermatitis caused by $O$. bursa in Brazil was in the Viamão municipality of Rio Grande do Sul (RIBEIRO et al., 1992). In the city of Santa Maria, also in Rio Grande do Sul, O. bursa was found in a nest of Myiodynastes maculatus (Passeriformes: Tyrannidae) located in the air-conditioning exhaust vent of a residence in which the people living there were bitten by these mites (OLIVEIRA et al., 2012).

Mentz et al. (2015) reported bites on humans from an abandoned nest of Furnarius rufus (Passeriformes: Furnariidae) in the city of Porto Alegre (Rio Grande do Sul). Ornithonyssus bursa was also collected on Columbina picui (Columbiformes: Columbidae) in the cities of Pelotas and Capão do Leão (Rio Grande do Sul), although in this case, there were no reports of human bites (COIMBRA et al., 2012).

In the present study, we report bites on humans and new occurrence of $O$. bursa based on material deposited in the Acari Collection of the Instituto Butantan (IBSP).

\section{Materials and Methods}

\section{Material identification}

Voucher species of the family Macronyssidae deposited in Acari Collection of the Instituto Butantan, São Paulo, Brazil (IBSP) were examined. Specimens in alcohol were slide-mounted with Hoyer's medium according to Walter \& Krantz (2009). All specimens were identified in accordance with Guimarães et al. (2001), Radovsky (2007) and Denmark \& Cromroy (2003). Micrographs of four specimens (IBSP 12804) were made by the Low Temperature Scanning Electron Microscopy (LT-SEM) at the US Department of Agriculture, Electron and Confocal Microscopy Unit, Beltsville, Maryland following Dowling et al. (2010) and Bolton et al. (2014).

\section{Receiving material}

Some of the samples were sent to the IBSP by people that were bitten by these mites. All the mites had been collected by people in their homes, mainly in their beds and couches; these people warned that they had been bitten. Including, one of these cases was reported by the last author, DMB-B that was housed in a house in Parana state, and was bitten by these mites.

\section{Molecular analysis}

DNA extraction using the Guanidine Isothiocyanate Lysis Protocol (CHOMCZYNSKI, 1993), was individually performed on three specimens (access number IBSP 12804), placed in an Eppendorf microtube and punctured in the idiosomal region with a sterile needle $(1.20 * 40-18 \mathrm{G})$. After the DNA extraction, the specimens were recovered, mounted on slides and kept as vouchers.

A conventional PCR targeting a 500-pb fragment of the $18 \mathrm{~S}$ ribosomal RNA gene was performed using primers Mite18S-1F (3'-ATATTGGAGGGCAAGTCTGG-5') and Mite18S-1R (3'-TGGCATCGTTTATGGTTAG-5') as described by Otto \& Wilson (2001). For each reaction, negative (Milli-Q water free of DNA) and positive controls were used. All PCRs were performed in a Mastercycler Gradient (Eppendorf ${ }^{\circledR}$ California, USA). PCR products with concentrations higher than $20 \mathrm{ng} / \mu \mathrm{l}$ were selected and purified with ExoSap-IT (GE Healthcare Pittsburgh, PA). Sanger sequencing of the samples was performed in the "Centro de Pesquisa sobre Genoma Humano e Células Tronco do Instituto de Biociências da USP”. Obtained sequences were assembled with Sequencing Analysis 5.3.1 software and submitted to BLAST analyses (ALTSCHUL et al., 1990) in order to infer similarities with other mites available in GenBank. Different haplotypes were visually discriminated after an alignment using CLUSTAL W algorithm (THOMPSON et al., 1994) implemented in Geneious R9 (KEARSE et al., 2012).

\section{Results}

Specimens deposited in the IBSP collection under the accession numbers IBSP 157, IBSP 884, IBSP 903, IBSP 1868, IBSP 3579 , IBSP 5639, IBSP 5661, IBSP 11984, IBSP 12650, IBSP 12734 , IBSP 12804, IBSP 13663, IBSP 14355 were identified as $O$. bursa and were collected parasitizing birds or in bird nests. The differential diagnosis for this species is represented by the setae at the posterior corners of the sternal shield, common posterior margin of the dorsal shield with 4 pairs of setae (Figures 1 and 2).

The samples under the accession numbers IBSP 11984, IBSP 12650, IBSP 12734, IBSP 12804, IBSP 13663 and IBSP 14355 were also associated with humans who were bitten. In these cases, the people reported that the clinical signs consisted of papular dermatitis, and the scratching of these papules resulted in large inflamed areas, as shown in Figure 3. According to people who were bitten, the itching persisted for at least 5 days, even after treatment with antihistamines. The dermatitis shown in Figure 3 was taken by Dr. Darci Moraes Barros-Battesti shortly after being 

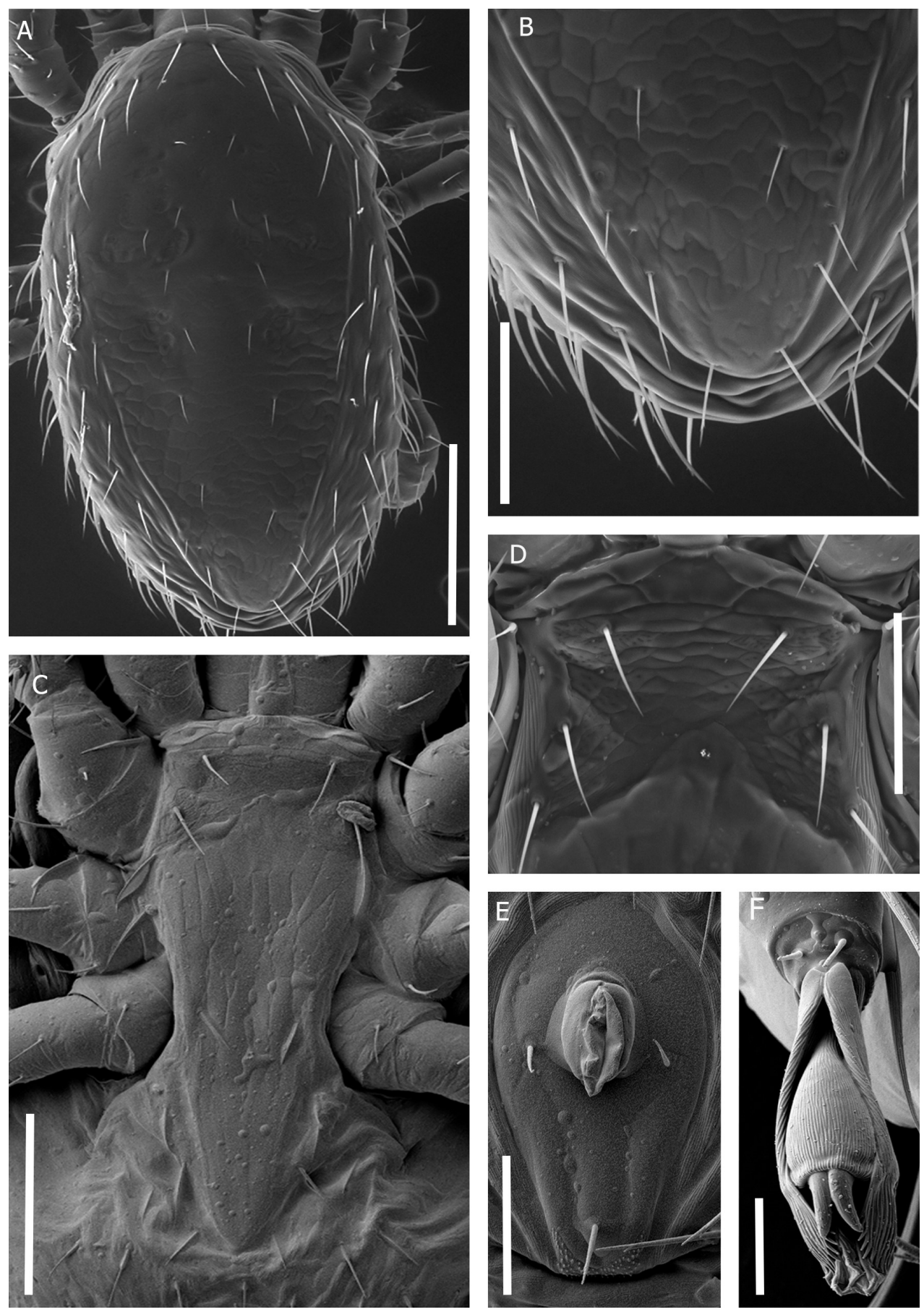

Figure 1. Morphological details of Ornithonyssus bursa. A - entire dorsal shield; B - posterior margin of the dorsal shield; C - genital shield; D - three pairs of setae inside the sternal shield; E - anal shield; F - claw of the tarsus of the leg II. Scale bars: A and C 300 $\mu$ m, B and D 100 $\mu$ m, E $50 \mu \mathrm{m} ; \mathrm{F} 10 \mu \mathrm{m}$.

bitten. In conversation with these people that were bitten, they said that they were only bitten during the night.

\section{Material Examined}

5 q (IBSP 157), Butantan, São Paulo, São Paulo state, Brazil (460 38' 09" W, 23o 32' 52" S, elevation: 760m), 18-XI-1935, Gallus gallus domesticus (Galliformes: Phasianidae); 10 (IBSP 884), same locality and host, 22-IX-1936; 10 (IBSP 903), same locality and host, 6-X-1936; 1 q (IBSP 1868), Sabaúna, Mogi das Cruzes, São Paulo state, Brazil (4605' 09” W, 23 28’ 48” S, elevation: 742m), 01-VIII-1948, Pygochelidon cyanoleuca (Passeriformes: Hirundinidae), N. Bolognani coll.; 2 q (IBSP 3579), Maracaná, Rio de Janeiro, Rio de Janeiro state, Brazil (43 13' 43.67" W, $22^{\circ} 54^{\prime} 48.3^{\prime \prime} \mathrm{S}$, elevation: 2m), same data, G. g. domesticus; 1 (IBSP 5639), São José dos Campos, São Paulo state, Brazil (45 53’ 12” W, 

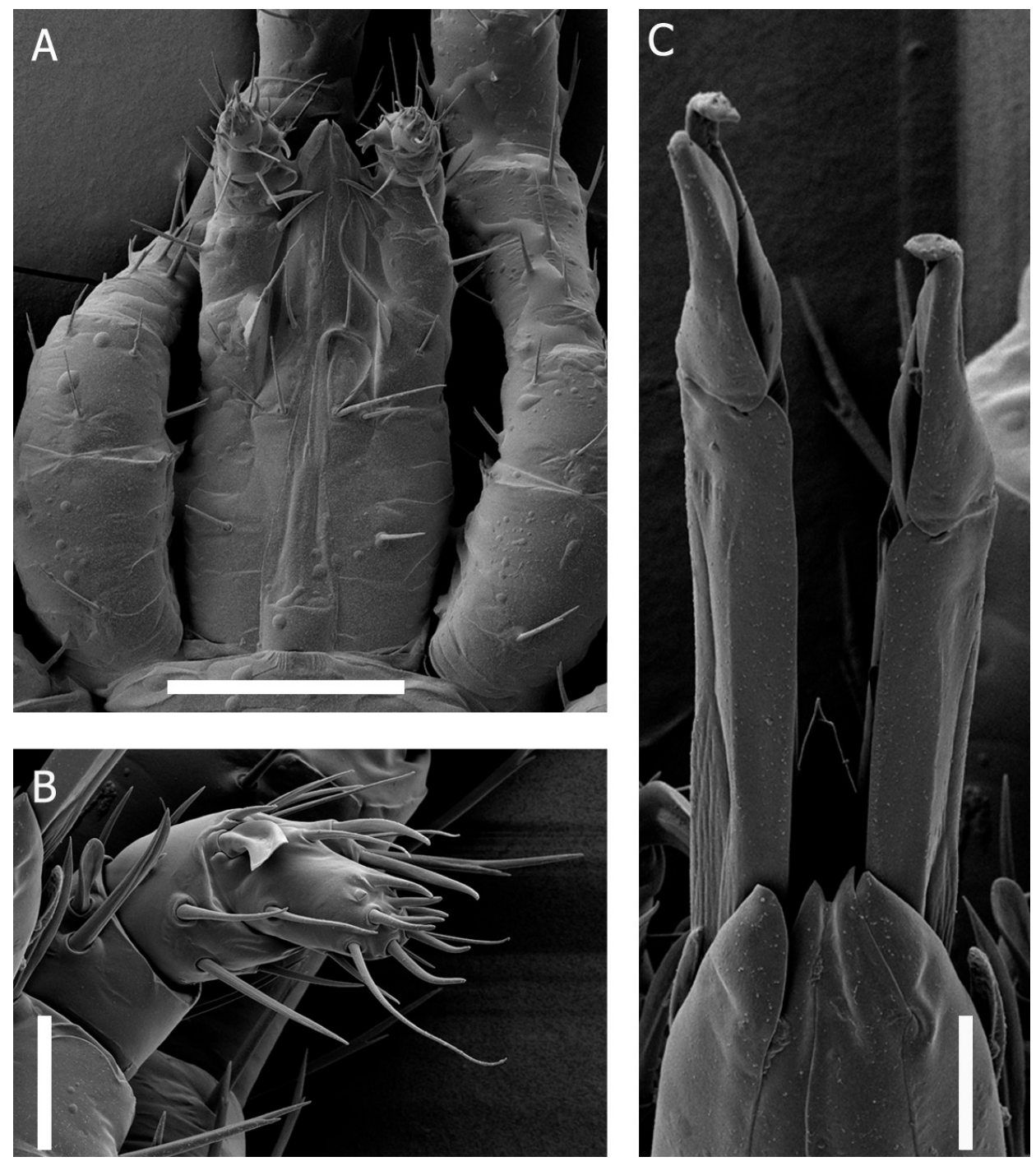

Figure 2. Morphological details of Ornithonyssus bursa. A - ventral view of the gnathosoma; B - palpal tarsus; C - cheliceral blades; Scale bars: A $50 \mu \mathrm{m}, \mathrm{B}$ and C. $20 \mu \mathrm{m}$.

$23^{\circ} 10^{\prime} 46$ " S, elevation: 600m), 09-IV-1941, same host, O. N. Fagundes coll.; 6 + (IBSP 5661), Butantan, São Paulo, São Paulo state, Brazil, 12-IX-1958, G. g. domesticus, M. Nogueira coll.; 1 † (IBSP 11984), Jardim São Jorge, São Paulo, São Paulo state, Brazil (46 38’ 10” W, 23 32' 52” S, elevation: 760m), no data, unidentified bird nests and Homo sapiens (Primates: Hominidae); 3 9 (IBSP 14355), Vila Prudente, São Paulo, São Paulo state, Brazil (4634’ 48.2” W, $23^{\circ} 34^{\prime}$ 51.6” S), IX-2018, unidentified bird nests and Homo sapiens; 1 (IBSP 12650), Jardim Maristela, Itapevi, São Paulo state, Brazil (46 56' 02” W, 230 32' 57" S; elevation: 770m), 21-X-2016, unidentified bird nests and Homo sapiens; 4 + (IBSP 12734), Dois Vizinhos, Paraná state, Brazil (53 03' 25” W, 250 44' 01” S, elevation: 509m), 12-XI-2016, Columbina talpacoti (Columbiformes: Columbidae) and Homo sapiens; 1 (IBSP 12804), Botucatu, São Paulo state, Brazil (48 26' 41” W, 22o 53' 10” S, elevation: 804m), I-2016, same hosts; 1 ( (IBSP 13663), Jaboticabal, São Paulo state, Brazil
(48 19' 20" W, 21 15' 18” S, elevation: 605m), X-2017, Zenaida auriculata (Columbiformes: Columbidae) and Homo sapiens.

\section{Molecular analysis}

Three specimens (IBSP 12734) of $O$. bursa were submitted to PCR. One of the three samples submitted to PCR amplified a fragment of 443-bp (GenBank accession number: MG966210). BLAST comparisons of these sequences showed 98.1\% (407/415-bp) of identity with homologous sequences from O. bursa (FJ911854).

\section{Discussion}

Over the years many studies recorded the presence of Ornithonyssus sylviarum (Canestrini \& Fanzago, 1877), a species similar to O. bursa, parasitizing several birds in Brazil (FACCINI \& MASSARD, 1974; PEREIRA et al., 1977; FACCINI, 1987; 

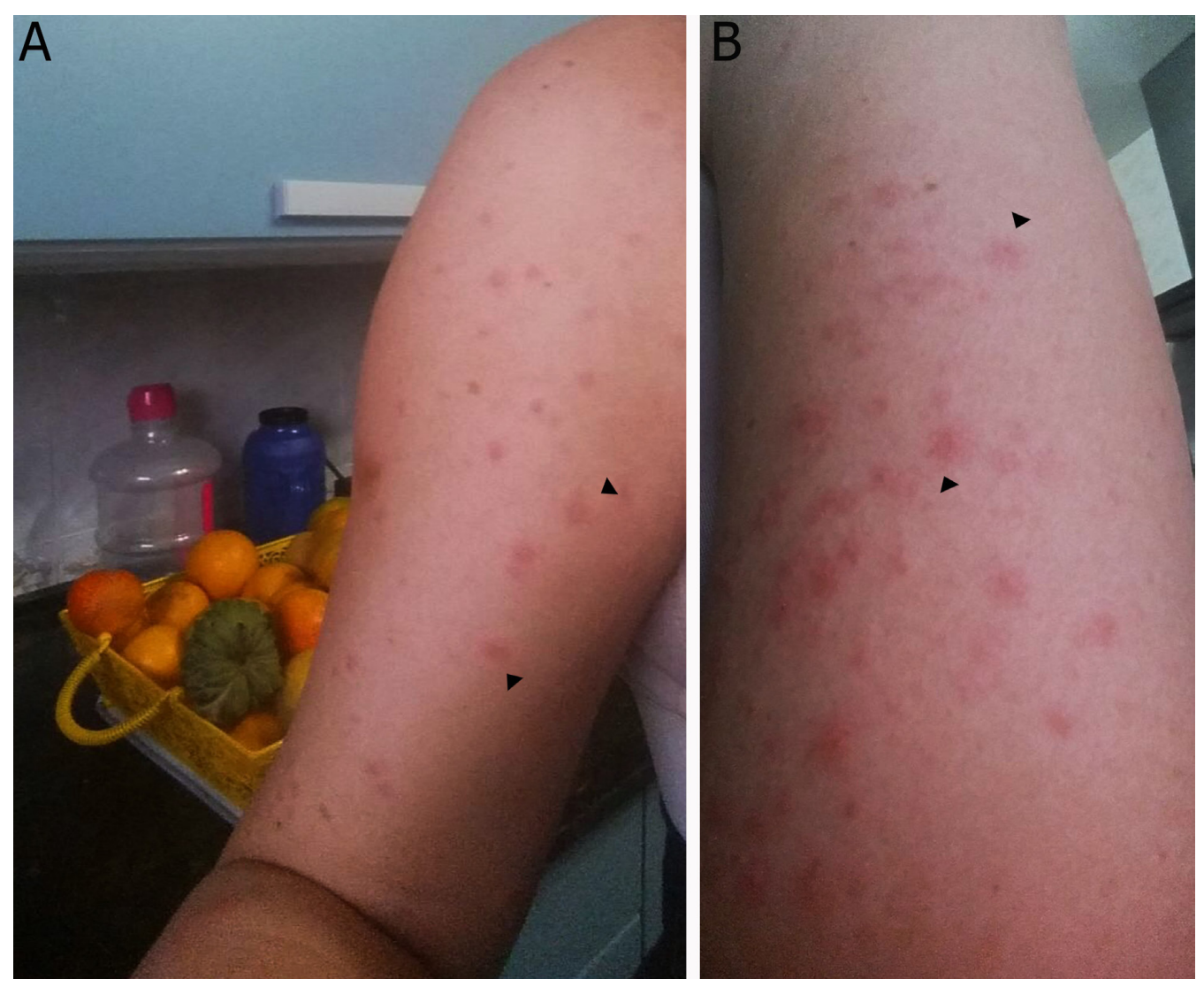

Figure 3. Papular dermatitis. A. Person's arm bitten by Ornithonyssus bursa; B. Details of the papular dermatitis on the person's arm. The Black arrows show the areas of papular dermatits.

FACCINI et al., 1991; SERAFINI et al., 2003; SOARES et al., 2008). To have a clear separation between these two species, the main differences are: posterior margin of the dorsal shield of $O$. sylviarum much narrower than in $O$. bursa. In addition, $O$. bursa has three pairs of setae on the sternal shield, while O. sylviarum usually has two pairs of setae (DENMARK \& CROMROY, 2003; DI PALMA et al., 2012).

The specimens from Dois Vizinhos (IBSP 12734) were collected on the humans living in the house, near the air conditioning exhaust vents. This situation was also observed by Oliveira et al. (2012). Currently only dermatitis has been observed on humans, there are no records about transmission of pathogens through the bite of $O$. bursa.

The examined materials in the present study are new locality records in State of São Paulo (Botucatu, Jaboticabal, Mogi das Cruzes and São José dos Campos), Rio de Janeiro (Maracanã) and Paraná (Dois Vizinhos). The passerine Pygochelidon cyanoleuca (Passeriformes: Hirundinidae) is a new association with $O$. bursa.

In addition, we also obtained a partial $18 \mathrm{~S}$ sequences from one specimen. This sequence is quite similar $(-98 \%)$ to the sequence cited by Dowling \& O'Connor (2010). This is greater $18 \mathrm{~S}$ divergence than typically expected for conspecifics; however, the sequence from this study is only a partial $18 \mathrm{~S}$ and all of the differences between the two sequences fall within the most variable region of the gene. Additionally, the mites were from geographically disparate areas. Both of these factors could lead to increased levels of divergence and it would be interesting to see what genetic divergence looks like from $O$. bursa around the world.

\section{Acknowledgements}

To Gabrielle Ribeiro de Andrade, Maria Cristina Ferreira do Rosário (CNPq no. 377343/2015-3 and 377342/2015-7, respectively) and Andrew Ulsamer for technical contributions. This work was supported by the Conselho Nacional de Desenvolvimento Científico e Tecnológico (CNPq no. 454907/2014-1 to DMB-B and 377976/2014-8 to FCJ) and Fundação de Amparo à Pesquisa do Estado de Sáo Paulo (FAPESP no. 2017/01416-7 to RB-S). This study was financed in part by the Coordenação de Aperfeiçoamento de Pessoal de Nível Superior - Brazil (CAPES) - Finance Code 001. Mention of trade names or commercial products in this publication is solely for the purpose of providing specific information and does not imply recommendation or endorsement by the USDA; USDA is an equal opportunity provider and employer.

\section{References}

Altschul SF, Gish W, Miller W, Myers EW, Lipman DJ. Basic local alignment search tool. J Mol Biol 1990; 215(3): 403-410. http://dx.doi. org/10.1016/S0022-2836(05)80360-2. PMid:2231712. 
Aramburú R, Cicchino A, Bucher E. Material vegetal fresco en cámaras de cría de la cotorra argentina Myiopsitta monachus (Psittacidae). Ornitol Neotrop 2002; 13: 433-436.

Bolton SJ, Klompen H, Bauchan GR, Ochoa R. A new genus and species of Nematalycidae (Acari: Endeostigmata). J Nat Hist 2014; 48(23-24): 1359-1373. http://dx.doi.org/10.1080/00222933.2013.859318.

Chomczynski PA. Reagent for the single-step simultaneous isolation of RNA, DNA and proteins from cell and tissue samples. Biotechniques 1993; 15(3): 532-537. PMid:7692896.

Coimbra MAA, Mascarenhas CS, Müller G, Brum JGW. Phthiraptera and Gamasida parasites of Columbina picui (Temminck) (Columbiformes: Columbidae) in the State of Rio Grande do Sul, Southern Brazil. Braz J Biol 2012; 72(3): 583-585. http://dx.doi.org/10.1590/S151969842012000300022. PMid:22990830.

Denmark HA, Cromroy HL. Tropical Fowl Mite, Ornithonyssus bursa (Berlese) (Arachnida: Acari: Macronyssidae). IFAS Extension [online] 2003; (297): 1-3. [cited 2018 Dez 11]. Available from: https://edis.ifas. ufl.edu/in 575

Di Palma A, Giangaspero A, Cafiero MA, Germinara GS. A gallery of the key characters to ease identification of Dermanyssus gallinae (Acari: Gamasida: Dermanyssidae) and allow differentiation from Ornithonyssus sylviarum (Acari: Gamasida: Macronyssidae). Parasit Vectors 2012; 5(1): 104. http://dx.doi.org/10.1186/1756-3305-5-104. PMid:22647594.

Dowling APG, Bauchan GR, Ochoa R, Beard JJ. Scanning electron microscopy vouchers and genomic data from an individual specimen: Maximizing the utility of delicate and rare specimens. Acarologia 2010; 50(4): 479-485. http://dx.doi.org/10.1051/acarologia/20101983.

Dowling APG, O'Connor BM. Phylogenetic relationships within the suborder Dermanyssina (Acari: Parasitiformes) and a test of dermanyssoid monophyly. Int J Acarol 2010; 36(4): 299-312. http:// dx.doi.org/10.1080/01647951003604569.

Faccini JLH. Ácaros hematófagos: parasitos de aves de postura (Gallus gallus) no Brasil. Diversificação, biologia e controle. Arq Flumin Med Vet 1987; 2(1): 29-31.

Faccini JLH, Leite RC, Leite RC. Sobre três casos de parasitismo por ácaros. Arq Univ Fed Rur Rio de 1991; 14(1): 97-100.

Faccini JLH, Massard CL. Nota sobre a ocorrência de Ornithonyssus silviarum (Canestrini \& Fanzago) (Mesostigmata: Macronyssidae) em Gallus gallus L. no Brasil. Arq Univ Fed Rur Rio de Janeiro 1974; 4(1): 39-40.

Goulart TM, Moraes DL, Prado AP. Mites associated with the eared dove, Zenaida auriculata (Des Murs, 1847), in São Paulo State, Brazil. Zoosymposia 2011; 6: 267-274.

Guimarães JH, Tucci EC, Barros-Battesti DM. Ectoparasitos de importância veterinária. São Paulo: Editora Plêidade, Ltda. M.E.; 2001. 213 p.

Kearse M, Moir R, Wilson A, Stones-Havas S, Cheung M, Sturrock $S$, et al. Geneious Basic: An integrated and extendable desktop software platform for the organization and analysis of sequence data. Bioinformatics 2012; 28(12): 1647-1649. http://dx.doi.org/10.1093/bioinformatics/ bts199. PMid:22543367.

Mascarenhas CS, Coimbra MAA, Müller G, Brum JGW. Ocorrência de Ornithonyssus bursa (Berlese, 1888) (Acari: Macronyssidae) em filhotes de Megascops choliba (Corujinha-do-mato) e Pitangus sulphuratus (Bem- te-vi), no Rio Grande do Sul, Brasil. Rev Bras Parasitol Vet 2009; 18(4): 69-70. http://dx.doi.org/10.4322/rbpv.01804013. PMid:20040213.

Mentz MB, Silva GL, Silva CE. Dermatitis caused by the tropical fowl mite Ornithonyssus bursa (Berlese) (Acari: Macronyssidae): a case report in humans. Rev Soc Bras Med Trop 2015; 48(6): 786-788. http://dx.doi. org/10.1590/0037-8682-0170-2015. PMid:26676510.

Moraes DL, Goulart TM, Prado AP. Mites associated with the ruddy ground dove, Columbina talpacoti (Temminck, 1810), in São Paulo State, Brazil. Zoosymposia 2011; 6: 275-281.

Oliveira CB, Tonin AA, Monteiro SG. Parasitismo do ácaro Ornithonyssus bursa em humanos no Sul do Brasil. Acta Sci Vet 2012; 40(4): 1091.

Otto JC, Wilson KJ. Assessment of the usefulness of ribosomal $18 \mathrm{~S}$ and mitochondrial COI sequences in Prostigmata phylogeny. In: Halliday RB, Walter DE, Proctor HC, Norton RA, Colloff J, editors. Acarology: Proceedings of the 10th International Congress. Melbourne: CSIRO Publishing; 2001. p. 100-109.

Pereira MC, Oba MSP, Schumaker TTS. Ornithonysus sylviarum (Canestrini e Fanzago 1877) - (Mesostigmata: Macronyssidae) em Gallus gallus domesticus (L.) no Estado de São Paulo, Brasil. Rev Fac Med Vet Zootec Univ S Paulo 1977; 14(2): 243-251.

Post W. The prevalence of some ectoparasites, diseases and abnormalities in the yellow-shouldered blackbird. J Field Ornithol 1981; 52(1): 16-22.

Radovsky FJ. A new species of Ornithonyssus (Acari: Macronyssidae) in western North America and a review of nearctic species. Int J Acarol 2007; 33(3): 223-229. http://dx.doi.org/10.1080/01647950708684526.

Ribeiro VLS, Giora J. Infestação nas dependências internas de um laboratório farmacêutico por Ornithonyssus bursa (Acari: Macronyssidae) no Rio Grande do Sul, Brasil. Arq Fac Vet UFRGS 1994; 22: 70-75.

Ribeiro VLS, Moojen V, Telles APD. Caso clínico: Ornithonyssus bursa: parasito de aves causando acaríases cutâneas em humanos no Rio Grande do Sul, Brasil. An Bras Dermatol 1992; 67(1): 31-34.

Silva DE, Silva GL, Nascimento JM, Ferla NJ. Mite fauna associated with bird nests in Southern Brazil. Syst Appl Acarol 2018; 23(3): 426-440. http://dx.doi.org/10.11158/saa.23.3.2.

Semenas L, Rocha JA. Un motivo poco común de crisis de llanto en un recién nacido. Arch Argent Pediatr 1998; 96: 131-133.

Serafini PS, Anjos L, Arzua M, Volpato G, Vargas E, Polletto F. First Report of Ornithonyssus sylviarum (Acari: Macronyssidae) on black vulture (Coragyps atratus) nestlings from Brazil. Rev Bras Parasitol Vet 2003; 12(2): 92-93.

Soares NM, Tucci EC, Guastalli EAL, Yajima H. Controle da infestação por Ornithonyssus sylviarum (Canestrini e Fanzago, 1877) (Acari: Macronyssidae) em poedeiras comerciais utilizando extrato de Azadirachta indica. Rev Bras Parasitol Vet 2008; 17(4): 175-178. http://dx.doi.org/10.1590/ S1984-29612008000400001. PMid:19265573.

Thompson JD, Higgins DG, Gibson TJ. CLUSTAL W: improving the sensitivity of progressive multiple sequence alignment through sequence weighting, position-specific gap penalties and weight matrix choice. Nucleic Acids Res 1994; 22(22): 4673-4680. http://dx.doi.org/10.1093/ nar/22.22.4673. PMid:7984417.

Walter DE, Krantz GW. Collecting, rearing, and preparing specimens. In: Krantz GW, Walter DE (eds.). A manual of acarology. Lubbock: Texas Tech University Press. 2009.p. 83-96. 